\title{
SLOPE MASS RATING IN MIDDLE MOUNTAIN OF NEPAL: A CASE STUDY ON LANDSLIDE AT RABI VDC OPI VILLAGE, KAVRE
}

\author{
Kumud Raj Kafle \\ Department of Environmental Science and Engineering, \\ Kathmandu University, Dhulikhel, Nepal \\ Corresponding address: krkafle@ku.edu.np \\ Received 23 March, 2010; Revised 26 July, 2010
}

\begin{abstract}
The study landslide area lies on Opi Village Development Committee (VDC) of Kavre district at the north west (about $3 \mathrm{~km}$ ) of Dhulikhel Bazar and North east (about 4km) from Banepa Bazar of Nepal. The area is composed of rocks of Bhimphedi group of lesser Himalayan crystalline. The rock on this group comprises Precambrian green schists metamorphosed rocks of schist quartzite and few marble horizons. Geomorphologically, the failure site is located in between a stream gully on the toe and residual soil on the crown. Field observation, attitude measurements, sampling and lab analysis and GPS mapping are the main methods to find the dimension and characteristics of the landslide.
\end{abstract}

It is found that there are few major discontinuities that play the role for the rock/soil slides around the area. In the field measurement the orientation of the rock foliation around the area is $220^{\circ} / 35^{\circ}$. The major discontinuities are $205^{\circ} / 40^{\circ}$ and $150^{\circ} / 60^{\circ}$. These joint sets play the main role to the plane as well as wedge failures around the area.

Slope Mass Rating (SMR) is calculated based on values of Rock Mass Rating (RMR), other joints and slope orientation. The calculated value of SMR is 34, which indicates the calculated value lies on IV class (Bad), unstable having planner or big wedges failure of SMR and needs to be corrective measures in the slope. The calculated result matches the site condition and characteristics of the Opi land slides.

Key Words: Landslide, Discontinuities, Slope Mass Rating, Rock Mass Rating

\section{THE STUDY AREA}

The location of the landslide lies Opi Village Development Committee (VDC) of Kavre district at the north west (about $3 \mathrm{~km}$ ) of Dhulikhel Bazar and North east (about 4km) from Banepa Bazar. It is surrounded by Kutal Village in the south and Chapletidanda village in the east at about elevation from $1280 \mathrm{~m}$ to $1400 \mathrm{~m}$. It is bounded by the latitudes $27.6410^{\circ}$ and $27.6414^{0} \mathrm{~N}$, and the longitudes $85.5477^{\circ}$ to $85.5472^{\circ} \mathrm{E}$. The Jhiku Khola is the main draining river in the study area, which joins the Sunkoshi river. 


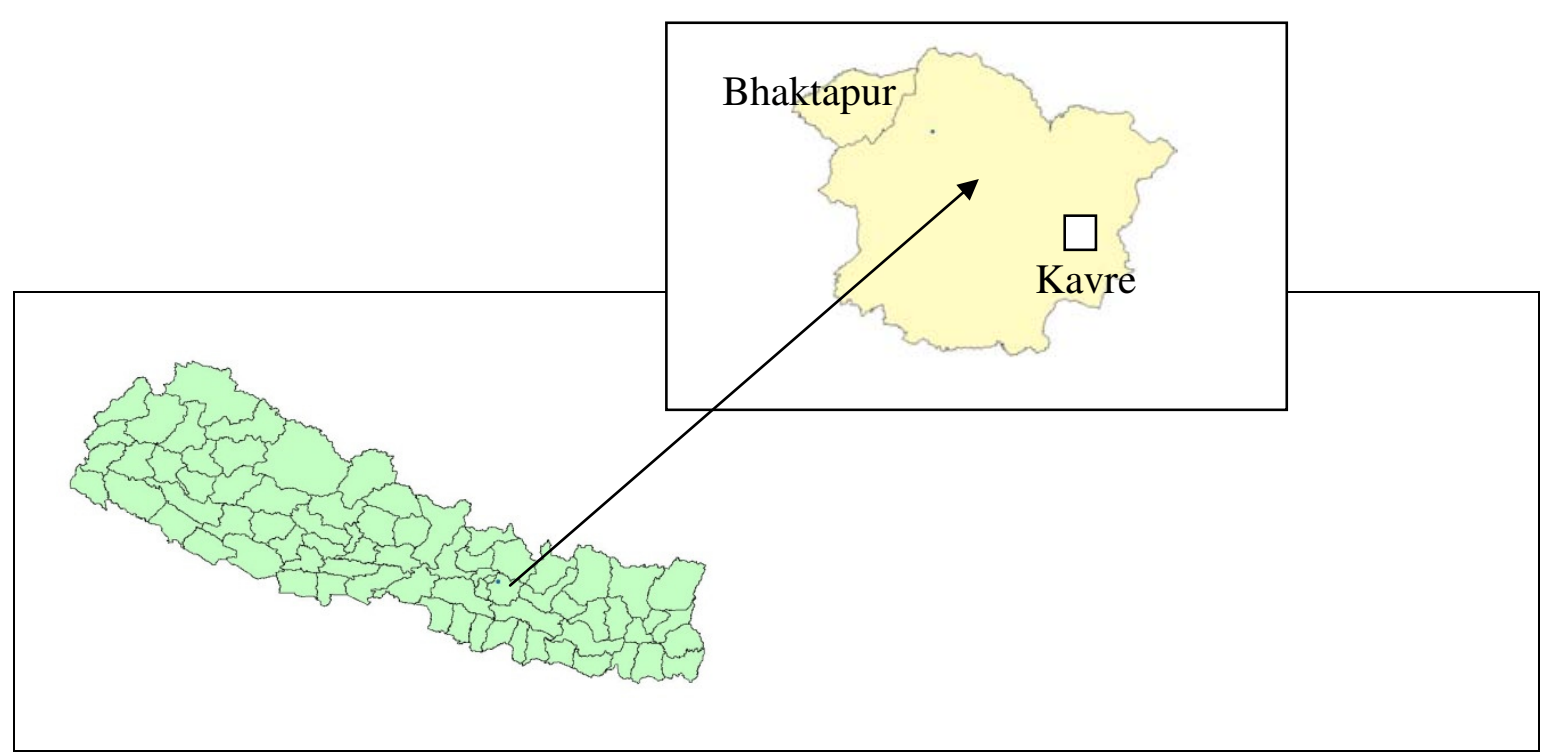

Fig. 1.1 Location map of the study area

The Southeastern part of the area is dissected by many streams and gullies and has rugged topography where as the northeastern part is comparatively smooth.

During the Aug-Sep 1994, a severe rainstorm hit the Jhiku watershed causing catastrophic landslides, floods and debris flows. The incident was responsible for heavy loss of property and washout the farm land of the downsides. The landslide damaged 3 residential houses and cattles, fortunately no one human casualty has occurred due to this land slide.

The most of the foothill of the area and southeastern part of the area has considerable human settlements as well as cultivation practice where as ridge and hills are covered by forest on the northern portion of the hills.

\section{GEOLOGICAL AND GEOMORPHOLOGICAL SETTING OF THE STUDY AREA}

The Lesser Himalayan Crystalline is made of bedded sequence of metassediments with occasional fossiliferous rocks lying over the low grade metamorphism as klippen in the Lesser Himalaya. The thrust sheets rooted in the Higher Himalaya are preserved in the longitudinal synclinal structures in the Lesser Himalaya while in some areas (eg. Kathmandu, Bhojpur, Ilam etc), these crystalline are physically continuous with the higher himalaya crystallines without discernable break. The lesser Himalaya crystalline in Kathmandu and Central Mahabharat Region are divided into the older Bhimphedi group consisting of muscovite biotite schist, quartize and marble, and the Phulchoki Group represented by argillo-arenaceous to argillo-calcareous rocks containing Silurian Trilobite and Cambro-Ordovician to Devonian Brachipods and Crinnoids. The group considered as the equivalent of Paleozoic Tethys sedimentary rocks of the Higher Himalaya. 


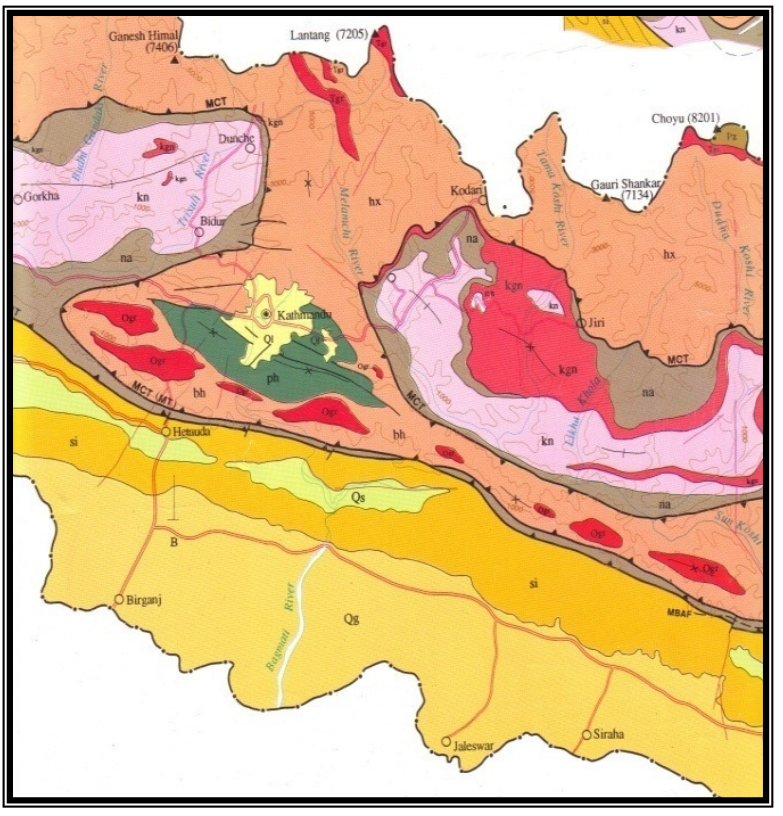

Fig. 2.1 Geological Map of the study area (DGM, 1994)
Geologically the area lies on Bhimphedi group of lesser Himalayan crystallines. The rock on this group comprises Precambrian green schists metamorphosed rocks of schist quartzite and few marble horizons. Locally migmatised and gneissifed, Granite intrusions are also presents that equivalent to Precambrian rocks of the Higher Himalaya Crystallines. The upper part of the area composed of Higher Himalayan Crystalline that includes the Precambrian high grade metamorphic rocks comprising gneisses, quartzites and marbles. Migmatites and granite gneisses present predominantly in the upper part (Geological Map of Nepal, 1994).

\section{METHODOLOGY}

Field visits and measurements of discontinuities are the main methods for finding the SMR. For this Bieniawski geomechanics classification of Rock Mass Rating (RMR) system has been used to find M. R. Romana's Slope Mass Rating (SMR).

In 1974, Z. T. (SMR). Bieniawski published the details of a rock mass classification. This classification schemes is now universally used to classify the rock mass. It is also known as Geomechanics classification of rock masses or the RMR system.

The Rock Mass Rating (RMR) or Geomechanics system uses five basic parameters for classification and rock mass properties evaluation. A sixth parameter helps further assess issues of stability to specific problems. The RMR uses six parameters that are easily determined in the field.

- Uniaxial compressive strength of the intact rock

- Rock Quality Designation (RQD)

- Spacing of discontinuities

- Condition of discontinuities

- Groundwater conditions

- Orientation of discontinuities

In 1993, M. R. Romana of Universidad Politecnica Valencia, Spain proposed Slope Mass Rating (SMR) and he recommended a relationship to obtain SMR from RMR. He recommended some adjustment factors depending on the joint and slope relationship (usually of negative value) and a factor depending on the method of excavation (usually positive value). The relationship defined by Romana is as follows.

$\mathrm{SMR}=\mathrm{RMR}+\left(\mathrm{F}_{1} \times \mathrm{F}_{2} \times \mathrm{F}_{3}\right)+\mathrm{F}_{4}$ 
Where,

- $\quad$ RMR is Rock Mass Rating

- $\mathrm{F}_{1}$ depends on parallelism between joints and slope face strikes. Its range is from 1.00 to 0.15 . Romana gave these values empirically but he also proposed following relationship.

$$
\mathrm{F} 1=(1-\sin \mathrm{A})^{2}
$$

Where, A denotes the angle between the strike of the slope face and strike of discontinuities face.

- $\mathrm{F}_{2}$ represents joint dip angle in the planner mode of failure. In a sense it is a measure of the probability of joint shear strength. Its value ranges from 1.00 to 0.15

- F3 gives the relationship between the slope face and joint dip. In a planner mode of failure F3 refers to the probability that joints "daylight" in the slope face. Condition fair when slope face and joints are parallel. When the slope dips more than joints, very unfavorable conditions occur.

- F4 is the adjustment factor for the method of excavation.

Finally rated SMR values are classified as describes below

Table 1: SMR Classes defined by Romana (1993)

\begin{tabular}{|l|l|l|l|l|l|}
\hline Class & SMR & Description & Stability & Failures & Support \\
\hline I & $81-100$ & Very good & $\begin{array}{l}\text { Completely } \\
\text { Stable }\end{array}$ & None & None \\
\hline II & $61-80$ & Good & Stable & $\begin{array}{l}\text { Some } \\
\text { Blocks }\end{array}$ & Occasional \\
\hline III & $41-60$ & Normal & $\begin{array}{l}\text { Partially } \\
\text { stable }\end{array}$ & $\begin{array}{l}\text { Some joints } \\
\text { or many } \\
\text { wedges }\end{array}$ & Systematic \\
\hline IV & $21-40$ & Bad & Unstable & $\begin{array}{l}\text { Planner or } \\
\text { Big wedges }\end{array}$ & Importance/corrective \\
\hline V & $0-20$ & Very bad & $\begin{array}{l}\text { Completely } \\
\text { Unstable }\end{array}$ & $\begin{array}{l}\text { Big planner } \\
\text { or soil like }\end{array}$ & Re-excavation \\
\hline
\end{tabular}

\section{RESULTS}

Field observation showed that the sliding materials mainly composed of brown to yellow colored completely weathered colluvial soil. The percentage of the fines (mainly silt) in the debris is predominant. Composition of sliding materials on the toe of the landslide is bouldery gravelly soil with significantly fines. The rock fragments in the sliding material vary its sizes from silt to boulder. 


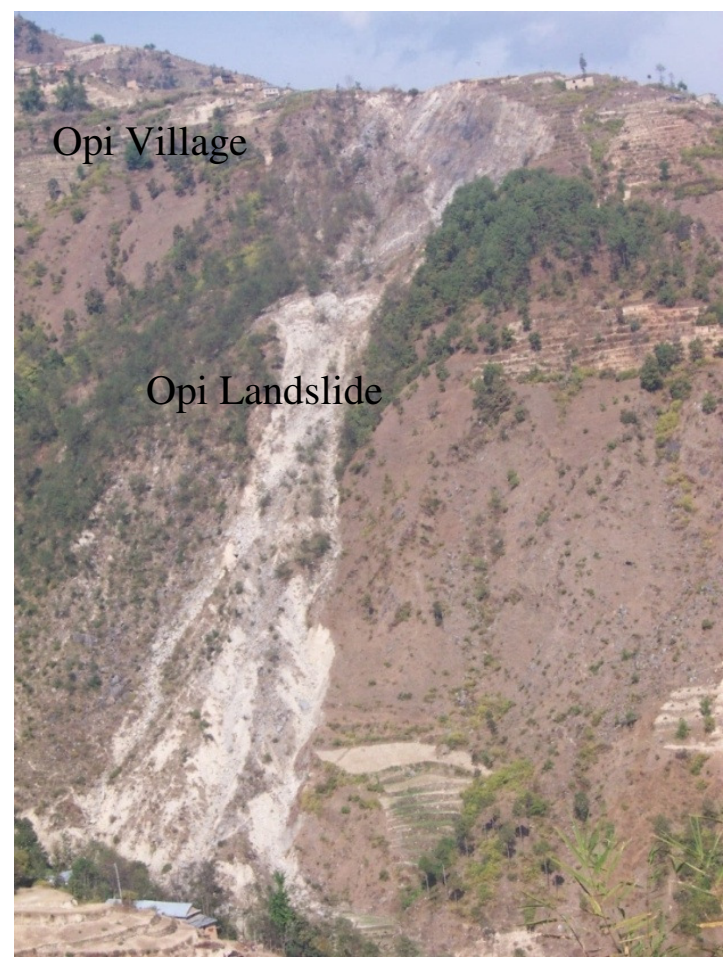

The bed rock of the area comprises of metasedimentary to weakly metamorphosed rocks. The main rock types in the area are gneiss and quartzites and phyllites. Yellow and brown colored weathered massive phyllite and soft, weathered and fractured gneiss are predominant. Rocks around uphill side of landslide area belong to Bhimphedi formation with southern dipping.

Geomorphologically, the failure site is located in between gully on the toe and residual soil on the crown along with old debris deposit on the left side. The topographical map and aerial photo of the area clearly show the typical stream pattern and its erosion activities.

Fig. 4.1 The study area in Kavre

From the meteorological point of view, the month of July and August are very critical for the study area. Plotting of average rainfall data from 2000 to 2008 of Nagarkot revealed that month of July and August of every year has received maximum rainfall. Variations of rainfall and air temperature are plotted in Fig. 4.2.
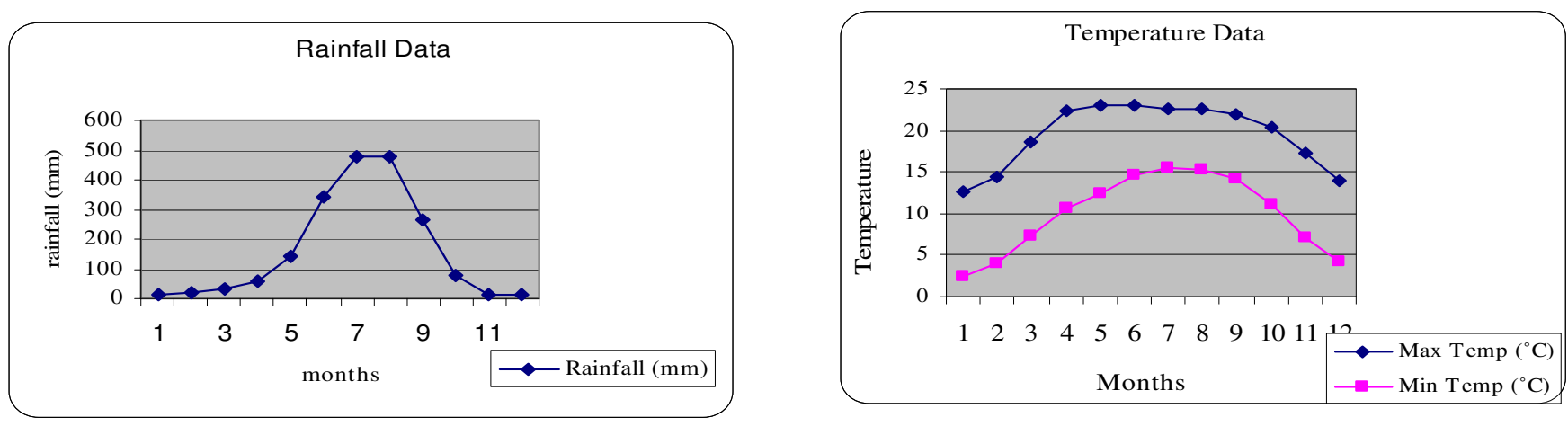

Fig. 4.2 Average Maximum, Minimum, Temperature $\left({ }^{\circ} \mathrm{C}\right)$ and rainfall $(\mathrm{mm})$ of Nagarkot from 2000 to 2008

\section{Rock Types}

The rock types around the slide area are quartzite and gneiss. Quartzite is grey to brownish white and gneiss is grey in color. The rocks are interacted with phyllite in some of the places of the area. The phyllite layer is helping to the slide in different places 
around the study area. The most of the rock exposures are along the stream that joins to Jikhu Khola.

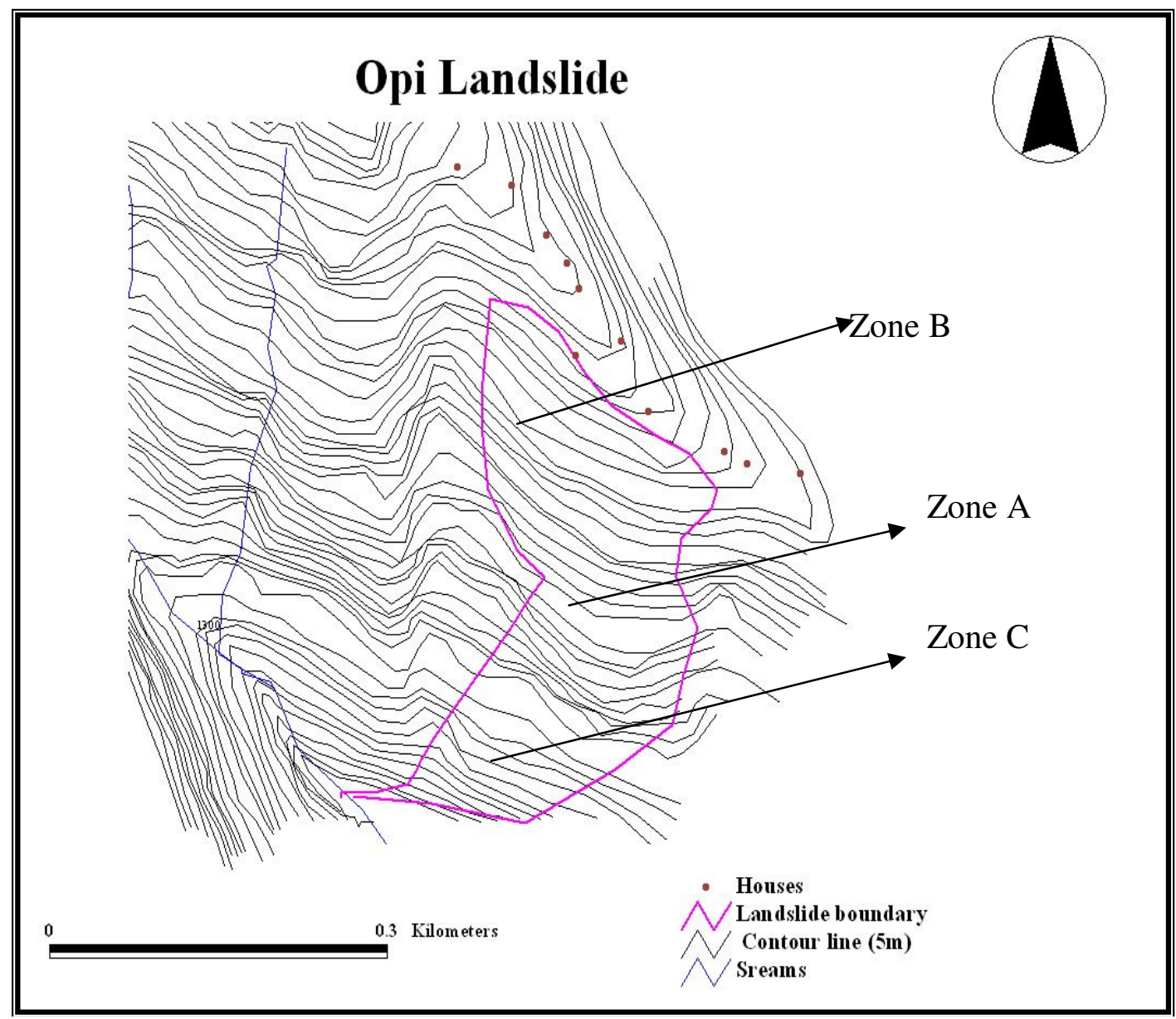

Fig. 4.3 Landslide map prepared during the field study with the help of GPS

The Opi landslide is divided into 3 Zones on the basis of its failure and depositional nature.

\section{Zone A}

Basically zone A comprise the landslide crown, scar and top of the body. On the crown of the slide, few residential buildings are also observed. Little vegetations (grass) along with $0.5 \mathrm{~m}$ thick top soil and south faced slope of the ridge that extends up to the western foot hill of the Panchkhal Valley. Zone A is further classified into three parts:

1) Eastern Plane failure

2) Mid Wedge failure and

3) Western Wedge failure 


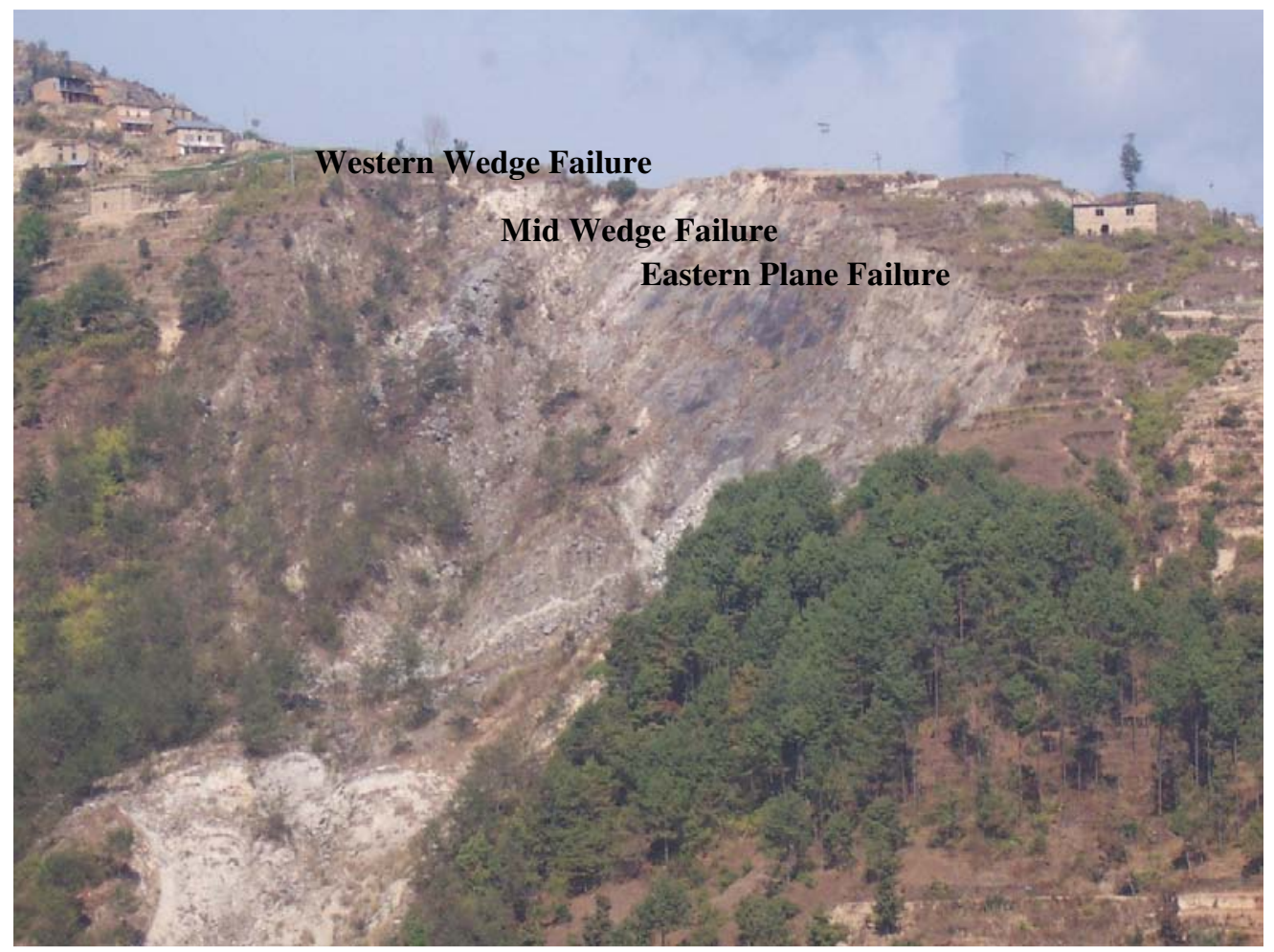

Fig. 4.4 Landslide Photo (upper part of the slide)

The eastern plane failure is observed fresh with clay filling along with slightly undulated and it is very favorable to plane failure due to daylight condition of the natural slope and the dip amount of the rock discontinuity. The attitude of the slope discontinuity is $205^{\circ} / 40^{0}$. The friction angle of the Gneiss is $23^{0}-29^{0}$, that indicates the slope is very favorable to the plane failures.

Similarly, the plane is extended to the westward along the ridge and makes a wedge to the joint $145^{\circ} / 60^{\circ}$. The rock of mid wedge is also fresh.

Again with same wedge due to the same discontinuities as mid wedge, the western failure has been occurred and it is older than that of the mid wedge.

\section{Zone B}

It is mid part of the slope and it is top of the body of the landslide. The landform indicates that the zone it little flatter along the slope. Right part is covered with the forest and left part of the zone by the low dense forest. On both sides to the zone is made of old colluvial debris. These parts are almost stable due to its angle of repose and vegetation. Two rills are initiated from this part to the downwards the slope or along the slide material. However, the water collection or surface runoff is started from the crown of the slide basically from mid and western wedges.

\section{Zone $C$}

It is the lower part of the landslide. The zone is made by the slide materials comprises quartizites, gneiss and phyllite colluviums. The colluviums consist of fine materials to the 
huge boulders. The material extends downwards to the stream that flows towards the east or Panchkhal Valley. The soil thickness at end of failure zone is situated around the elevation of $1270 \mathrm{~m}$ with thickness of 4 to $5 \mathrm{~m}$. The Unified Soil Classification of Soil (USCS) shows that the soil type of the failure area ranged between GM-GC to SM-ML with huge amount of gravel. The properties of such material are as USCS.

Table 2 Soil Classification and Properties

\begin{tabular}{|l|l|}
\hline USCS & GM -GC \\
\hline GeoTechnical Name & Silty to Clayey Gravel \\
\hline Grain size distribution & $\begin{array}{l}\text { Clay 6\%, Silt 22\%, sand 30\% \& gravel } \\
42 \%\end{array}$ \\
\hline Liqid limit/Plastic limit & $\begin{array}{l}\text { Liquid Limit(Wl) }=19 \%, \text { Plastic Limit } \\
(\mathrm{Wp})=13 \% \text { and Plasticity Index (PI) }=6 \%\end{array}$ \\
\hline Density & $2.19+/-0.2 \mathrm{t} / \mathrm{m}^{3}$ \\
\hline Porosity & $28+/-7 \%$ \\
\hline Sharing Strength Index & $\varphi^{\prime}=33+/-3$ and c' $=0.2$ \\
\hline Compresibility & \\
\hline Permiability & $10^{4}-10^{6} \mathrm{~cm} / \mathrm{s}$ \\
\hline Source: Adopted
\end{tabular}

Source: Adopted from Krahenbuhl and Wagner (1983).

\section{Major Discontinuities}

There are four major discontinuities that play the role for the rock/soil slides around the area. These discontinuities are given in the table 3 below.

Table 3 Major discontinuities and attitudes

\begin{tabular}{|l|l|l|}
\hline Major Discontinuities no. & Dip Direction (Azimuth) & Dip Amount \\
\hline 1 & $220^{0}$ & $3^{0}$ \\
\hline 2 & $150^{0}$ & $6^{0}$ \\
\hline 3 & $315^{0}$ & $6^{0}$ \\
\hline 4 & $205^{0}$ & $4^{0}$ \\
\hline
\end{tabular}

The foliation is of the phyllite and rocks around the area are $220^{\circ} / 35^{\circ}$. The major discontinuities are $205^{\circ} / 40^{\circ}$ and $150^{\circ} / 60^{\circ}$. These joints sets play the main role to the plane as well as wedge failures around the area.

\section{Rock Mass Rating (RMR) and Slope Mass Rating (SMR)}

\section{Calculation of SMR}

RMR from the calculation as per standard chart $=37$

$$
\begin{aligned}
& F 1=0.7\left(20^{0}-10^{0}\right) \\
& F 2=1\left(\text { dipping more than } 45^{0}\right) \\
& F 3=-25\left(\text { difference is almost } 0^{0}\right)
\end{aligned}
$$




$$
\begin{aligned}
& \text { F4 = } 15 \text { (Natural Slope }) \\
& \begin{aligned}
\text { Then SMR } & =37+(0.7 \times 1 \times-25)+15 \\
& =34
\end{aligned}
\end{aligned}
$$

The calculated value lies on IV classes (Bad), unstable having planner or big wedges failure of SMR and needs to be corrective measures in the slope. The calculation results match the site condition and characteristics of the Opi land slides.

\section{The major factors of the Opi landslide}

The factors leading to large debris/rock- slides can be summarized by the presence of

- a structure of the mountain slopes

- an incline of slope between $45^{\circ}$ and $55^{\circ}$

- 4 sets of discontinuities and openings are 2.5 to $10 \mathrm{~mm}$

- several structural wedges, arranged on the slopes. The total of central and centro lateral wedges is greater than the total of lateral and very lateral wedges, the slide intended to be narrow and long.

- rocks of clay origin (Phyllite) closely interbedded with gneiss and with detrital rocks (sandstones, quartzite)

- a concave topography, as a more or less pronounced coomb.

There are of course a great variety of intermediate conditions existing between these extremes. The above findings are the major factors that made the rock slide.

\section{CONCLUSIONS}

The main conclusions of the study are:

1) The rainfall triggered landslide like Opi shows us very critical and vital roles of landslide hazard mapping.

2) It also shows us importance of hourly recorded rainfall/hydrological data that can be used to forecast disastrous nature of probable slide on the middle mountain.

3) Nevertheless, it is also better to use and develop more comprehensive method of physical modeling to predict the acceleration of landslide that suddenly loosed its strength and flows from steep slope to gentle slope.

4) From this study, it is also concluded that landslide hazard map should be quantified towards landslide risk assessment and management which decisively provides fruitful upshot to early warning system of landslide disaster.

\section{ACKNOWLEDGEMENT}

I would like to acknowledge colleagues of Department of Environment Science and Engineering, School of Science, Kathmandu University, specially Mrs. Shalu Adhikari, Miss Smriti Gurung and Dr. Rijan Bhakta Kayastha, for helping to carry out this study. I am very thankful to Miss Silu Bhochhibhoya to help in the field survey. Lastly, my 
heartfelt thanks go to the University Grant Commission (UGC) for the financial support for the research.

\section{REFERENCES}

1. Aulitzky, H., 1989. The debris flows of Austria. Bull. of the IAEG, v. 40

2. Biscuola E. and Turrini M. C. 2000. Study of a debris torrent in the Dolomites, Italy. Journal of Nepal Geological Society, Vol. 22

3. Bieniawski, Z. T., 1973. Engineering classification of jointed rock masses. The Civil Engineer in South Africa, 335-243

4. Brenner, P. 2003. Debris flow phenomena with some results from research in Europe, Proceedings of the Seminar and Workshop on Geoenvironmental Engineering Georisk / Mass Movements 23 - 24 July 2003, Bangkok, Thailand.

5. Caine, N., 1980. The rainfall intensity-duration control of shallow landslide and debris flow, Geogr. Ann., 62A (1-2).

6. Cruden, D.M. and Varnes D. J., 1996. Landslide Types and Processes. In Turner A.K. and Schuster R.L. (eds.), Landslides: Investigation and Mitigation. Sp. Rep.247, Transportation Research Board, National Research Council, National Academy Press, Washington D.C.

7. Dahal R. K., 2006. Geology for technical students, pp. 221-337.

8. Deoja, B., Dhital, M., Thapa, B., and Wagner, A. (Principal Editors), 1991. Mountain Risk Engineering Handbook, Published by ICIMOD, 875 p.

9. Dhital M. R., 2000. An overview of landslide hazard mapping and rating systems in Nepal, Journal of Nepal Geological Society, 2000, Vol. 22, pp. 533-538.

10. Dhital M. R., Upreti, B. N., Dangol, V., Bhandari A. N., and Bhattarai, A. 1991. Engineering Geological Methods Applied in Mountain Road Survey- An Example From Baitadi-Darchula Road Project (Nepal). Jour. Nepal. Geol. Soc., Vol. 7

11. DGM, 1994. Geological Map of Nepal, Kathmandu.

12. Geological Map of Nepal, 1994. Published by Department of Mines and Geology. 
13. Gray, D.H. and Leiser, D.A. 1982. Biotechnical slope protection and erosion control, New York, Van Mostrand Reinhold Company.

14. Hungr, O., 2000. Analysis of debris flow surges using the theory of uniformly progressive flow. Earth Surface Processes and Landforms 25.

15. Iverson R. M., 2000. Landslide triggering by rain infiltration, Water Resources Research, Vol. 36, No. 7, pp 1897-1910.

16. Jacob, M., Hungr, O., and Thomson, B., 1997. Two Debris Flows with anomalously high magnitude. Proc. of the First Int. Conf. on Debris Flow Hazards Mitigation: Mechanics, Prediction, and Assessment, San Francisco, California, pp. 382-394.

17. Krahenbuhl J., Wagner A. 1983. Survey, design, and construction of trail suspension bridges for remote areas, SKAT, Swiss Center for Appropriate Technology in St. Gallen, Switzerland.

18. Lee K. I., White W., and Ingles O.G., 1983. Geotechnical Engineering, Pitman Publishing Inc., Massachusetts 02050, USA, 508p

19. Legros F., 2002. The mobility of long-runout landslides, Engineering Geology 63 (2002), pp 301-331.

20. Romana M. R. 1993. A geomechanics classification for slopes: Slope Mass Rating. (In "Comprehensive Rock Engineering”. Ed. J. Hudson). Pergamon. Vol 3. Pp 575600.

21. Singh A., 1992. Modern Geotechnical Engineering, CBS Publishers and Distributors Pvt. Ltd., India, 846p.

22. Smith G. N., 1990. Elements of soil mechanics, Sixth edition, BSP Professional Books, London, 509p.

23. Sornette D., Helmstetter A., Andersen J. V., Gluzman S., Grasso J.-R. and Pisarenko V., 2003. Towards Landslide Predictions: Two Case Studies, Paper published in http://arxiv.org/abs/physics/0305067.pdf, 30p.

24. Stocklin, J. and Bhattarai, K. D. 1980. Geology of Kathmandu Area and Central Mahabharat Range, Unpublished UNDP Report.

25. UNDP Nepal, 2002. Systems of Recording Disaster Information in Nepal, presentation published in web address http://www.undp.org.in/dmweb/bsdisa/UNDPNEPAL.ppt

26. USBR (U.S. Bureau of Reclamation), 1963. Earth manual. First ed. revised, Washington DC, 783p. 